\title{
FREQUENT MONITORING OF WATER TEMPERATURE IN PEGAMETAN BAY, BALI: A PRELIMINARY ASSESSMENT TOWARDS MANAGEMENT OF MARINE AQUACULTURE DEVELOPMENT
}

\author{
I Nyoman Radiarta")\#, Erlania"), Ketut Sugama"), Hirmawan Tirta Yudha**), and \\ Masaaki Wada \\ ") Center for Aquaculture Research and Development, Jakarta \\ *) Research and Development Institute for Mariculture, Gondol, Bali \\ ***) School of Systems Information Science, Future University Hakodate, Hokkaido, Japan
}

(Received 18 September 2014; Final revised 7 November 2014; Accepted 10 November 2014)

\begin{abstract}
Aquaculture currently share for nearly half of the world's food fish consumption, and continue to be the fastest-growing animal food producing sector. The viability of aquaculture operation has greatly been affected by the characteristic of marine environment. Inventory and monitoring of marine environment are necessary and can be done through information technology implementation. Frequent monitoring of water temperature, for almost one year observation, at four aquaculture sites in Pegametan Bay and Research and Development Institute for Mariculture was investigated. Water temperature data were obtained by using logger and buoy systems. These data were contrasted against marine fish mortality. On the other hand, the suitability of species requirements with the thermal conditions was evaluated by comparing temperature range to the optimum and lethal temperature information available on marine fish species of aquaculture interest. This research could be beneficial for enhancing productivity of marine aquaculture operation in terms of possible impact of climate change. It was also possible to find the ideal temperature range for culturing fish species, taking into account the variability associated with large-scale phenomena.
\end{abstract}

KEYWORDS: Water temperature, site selection, marine fish aquaculture, climate change, Pegametan Bay

\section{INTRODUCTION}

Aquaculture continues to be the fastestgrowing animal food producing sector and currently accounts for $45.6 \%$ of the world's food fish consumption (FAO Fisheries and Aquaculture Department, 2011). In addition as sources of aquatic food production, aquaculture has a great potential for poverty allevia- tion and wealth generation for the people living in coastal area. The rapid growth of aquaculture in recent years has been consistent across sub-sectors. Aquaculture sector encompasses very small scale to very large-scale enterprises, implying that aquaculture can contribute significantly to a wide range of development needs (GESAMP, 2001). Despite the rapid growth trend, aquaculture development

\# Corresponding author. Center for Aquaculture Research and Development Jl. Ragunan 20, Pasar Minggu, Jakarta Selatan 12540, Indonesia. Phone: +62 217805052

E-mail: radiarta@yahoo.com 
continues to be hindered by number of constraints such as limited suitable site, concerns regarding impact on environment and multi-use conflicts (socio-economic). Improper aquaculture development may result in high discounting rate on the use of natural resources due to exploitation beyond carrying capacity. It has been suggested that the environmental impacts of aquaculture could be minimized or negated by the adoption of appropriate environmental safeguards, including regulatory, control, and monitoring procedures (GESAMP, 1996, 2001).

Mariculture is an important component of aquaculture production in Indonesia. According to the Ministry of Marine Affair and Fisheries (MMAF) (KKP, 2011 ), potential mariculture area in Indonesia is very large, reaching 12.5 million ha, but the utilization of this area is only 118 thousand ha $(<1 \%)$. This fact shows that mariculture area is still available for further development which needs proper strategic planning and management to ensure sustainable and environmentally sound for mariculture development in Indonesia. Recently, mariculture development in Indonesia has been accelerated with the MMAF national development plan, emphazising on increasing mariculture production for export, and domestic consumption as well as improving the income of coastal communities.

The success of marine aquaculture is fundamentally influenced by the complexity of aquatic environments ecology, which is becoming very important with the possible impact of global warming (IPCC, 2007). Mariculture development sites are generally located in highly vulnerable area to the effects of global warming. Coastal areas which are widely used for marine aquaculture activities, experiencing drastic changes in water temperature, receiving run off from the rivers, and polluted by human activities (anthropogenic), thus affecting the productivity level of the marine aquaculture (Callaway et al., 2012).

The viability of aquaculture operations has greatly been affected by the characteristic of marine environment. Inventory and monitoring of marine environment are necessary and can be done through analyzing either field measurement data or remotely sensed data. Water temperature is one important parameter that can affect fish growth performance. On the other hand, water temperature can also be used as indicator of possible impact of climate change on cultured species. Sea surface temperature has indicated increasing trend over 100 years of about $0.3^{\circ} \mathrm{C}-0.6^{\circ} \mathrm{C}$ (Cane et al., 1997). This situation may be as a result of human activity (anthropogenic), part of the natural climate change, or a combination of both aspects. Water temperature change could cause a growing number of diseases in farmed fish, both caused by viruses or bacteria. According to De Silva \& Soto (2009), an increase in sea water temperature in tropical regions might have a positive impact. In some cases, the increasing of sea temperatures could enhance growth performance and its productivity. However, the ranges of water temperature are expected to remain within the maximum range for cultivated species.

Pegametan Bay at the northern coast of Bali is a potential area for marine aquaculture development with a variety of potential species such as grouper, seabass, snapper, and milkfish. Hatchery system is performed well on land around the coastal area. This hatchery consists of complete system and small scale (household) system. In addition to marine fish cages are also developed well around the bay. Currently, the production of marine fish in this area is declining caused by fish disease and environmental change (water quality condition). The objective of this study was to observe the time series of sea water temperature in Pegametan Bay, Bali and to analyze the possible connection of sea water temperature to fish performance to determine the most suitable sea water temperature required for mariculture in Pegametan Bay, Bali.

\section{MATERIAL AND METHOD}

The study area located in Pegametan Bay and Gondol Research and Development Institute for Mariculture (GRDIM), northern part of Bali Island (Figure 1). Pegametan Bay is a potential area for mariculture development mainly for marine fish cage aquaculture. Fish species cultured in that area are seabass, grouper, and snapper. The cultured commodities are mainly based on high economically values (good price and widely accepted market). To support the productivity of marine aquaculture in the study area, monitoring water quality, especially sea water temperature is required.

Data collected in this study include field data and secondary data. Two digital HOBO loggers (ONSET $\mathrm{HOBO}^{\circledR}$ Water Temp Pro v2 U22-001) for sea water temperature was de- 

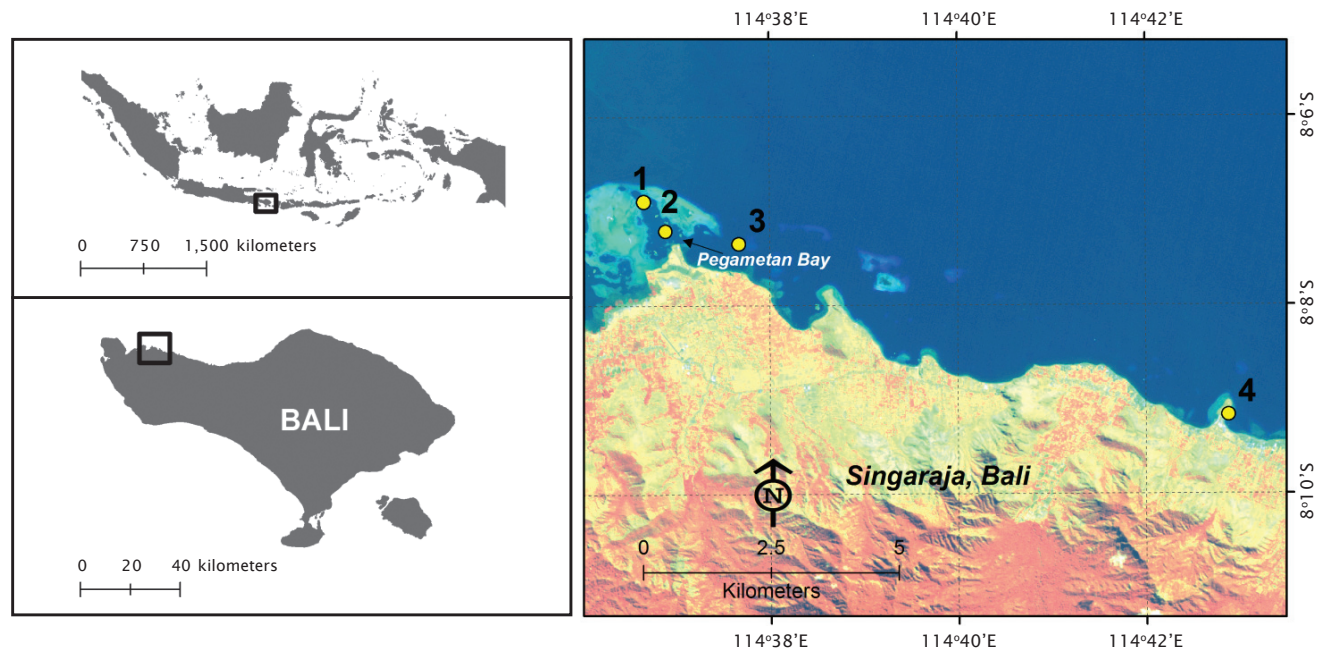

Figure 1. Geographic location of the logger (stations 1 and 4) and buoy (station 3) for frequent monitoring of sea water temperature at Pegametan Bay and RDIM, Bali. Arrow line indicates the mariculture area while station 2 is marine fish cage culture

ployed for at least one year in 2012 at two stations: center of the bay (station 1) and GRDIM (station 4) (Figure 1). In addition, one real time buoy for sea water temperature was also deployed outside the bay (station 3) with depth stratifications of 1,5 , and $10 \mathrm{~m}$ (Wada et al., 2013). All sensors were programmed to record sea water temperature at one hour intervals. Water temperature data containing 24hour and 12-hour periodic components, then the periodic components were removed and converted into a 24-hour moving average to find trends in water temperature change.

Number of fish mortality data were collected from one selected marine fish cage culture (station 2) in Pegametan Bay (Figure 1). Data were recorded daily from late February to December 2012. Satellite imagery of sea surface temperature (SST) from MODIS-Aqua sensor was used as secondary data in this study. Monthly level 3 GAC (global area coverage) data with $4 \mathrm{~km}$ resolution were obtained from DAAC/ GSFC/NASA from January to December 2012 (Savtchenko et al., 2004). Each image was georeferenced based on the WCS 84UTM zone 50 South coordinate system.

All water temperature recorded from the sensors and number of fish died were analyzed descriptively by drawing some graph in order to observe the seasonal trend among the data collection. We also computed moving average for all entire period of data. Finally to deter- mine potential site having suitable water temperature for culturing fish species, frequent monitoring of water temperature data were plotted in terms of frequency and temperature ranges.

\section{RESULTS AND DISCUSSION}

There is a close relationship between prevailing environmental conditions and the success of aquaculture production. This is largely because the health condition of fish is heavily dependent on environmental conditions, such as temperature, salinity, $\mathrm{pH}$, and dissolved oxygen (Stickney, 2009). The frequent monitoring of water temperature and number of fish died in the study area are presented in Figure 2. Analysis of frequent monitoring of water temperature showed seasonal variability. Water temperature was higher in December 2012 and lower in March 2012 (Figure 2A, B). High variations of water temperature were observed in Pegametan Bay station (Figure 2A) compare to RDIM station (Figure 2B). This variation might be caused by the placement of the logger sensors. Water temperature sensor in Pegametan Bay was deployed around the marine fish cage culture (open water), while in GRDIM, the sensor was deployed in inlet (closed system).

The highest water temperature $\left(31.35^{\circ} \mathrm{C}\right)$ in Pegametan Bay (station 1) was observed in December and the lowest $\left(26.70^{\circ} \mathrm{C}\right)$ was observed in March. Similar trend was also ob- 

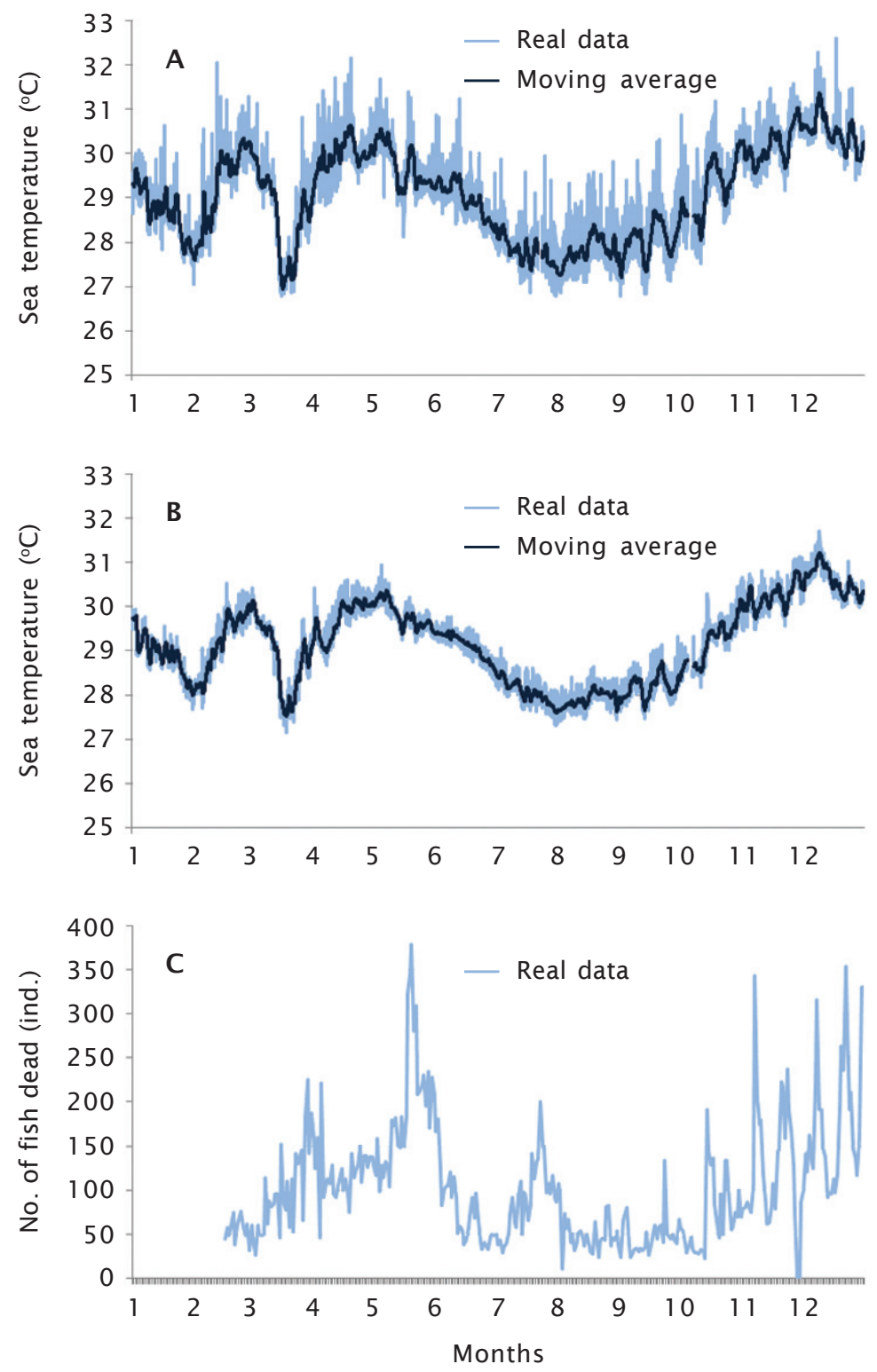

Figure 2. Raw data and moving average from the frequent monitoring of water temperature installed at Pegametan Bay (A) and Gondol Research and Development Institute for Mariculture (B), and number of fish died (C)

served in GRDIM (station 4). The high difference of water temperature recorded in Pegametan Bay greatly affected the growth of farmed fish. Water temperature were fluctuated in very short time. This situation could trigger the occurrence of fish disease (viral and bacterial) in fish farming.
Data on the number of fish died from one representative cage culture in Pegametan Bay is shown in Figure 2C. This figure indicated that the peak mortality of cultured fish occurred in May-June and November-December. It was clearly indicated that sudden temperature increase/decrease can affect maximum 
rate of fish mortality due to stress. Changes in water temperature could have affected fish performances such as stress (direct effect) and disease occurance (indirect effect) (De Silva $\&$ Soto, 2009). According to local fishermen, fish mortality occured in the study area mainly caused by fish desease. Albert \& Ransangan (2013) stated that stressful or sick fish will experience severe mortality when held in unfavorable conditions such as at high water temperature than in ideal water conditions. Stress in fish is often caused by high stocking density, handling, transportation and poor water quality. The fish has an optimum temperature range in order to grow well. Water that either warmer or colder than optimum ranges led to reduced growth. Intolerance towards water temperature change can cause disease or deaths occurrences.

In an intensive fish culture systems such as marine fish cage, fish are continuously exposed to variety of stressors. One of the factors that can cause stress to cultured fish is the water temperature changes. Changes in water temperature that follows the seasonal fluctuations is less risky for cultured fish. This is because the fish has the adaptability to the change of environmental conditions. This adaptability, generally refers to the reaction of fish towards the physical, physiological or chemical changes (Albert \& Ransangan, 2013).
Although the fishes could adapt to the environmental change, but they are constrained by the range of temperatures available in the environment. Increasing water temperatures can affect individual fish by altering physiological functions such as thermal tolerance, growth, metabolism, food consumption, reproductive success, and the ability to maintain internal homeostasis in the face of a variable external environment (Ficke et al., 2007).

Results of interviews with fish farmers and researchers in GRDIM stated that in May-July fish mortality frequently occurred due to the intrusion of cold water masses from Indian Ocean to the bay. This phenomenon was very clearly seen by using SST satellite imagery from MODIS Aqua sensor (Figure 3). This condition occurs repeatedly every year. Even in 2013 a change in water temperature has resulted in high abundance of jellyfish in Pegametan Bay (personal communication with Tatam Sutarmat).

The rate of temperature change affects the physiology and survival of cultured fish. In Figure 4, the stratify water temperature and difference of temperature in certain depth is plotted. The use of stratification water temperature sensor was intended to give in more detail about the variation of water temperature at different depth in Pegametan Bay. Water tem-
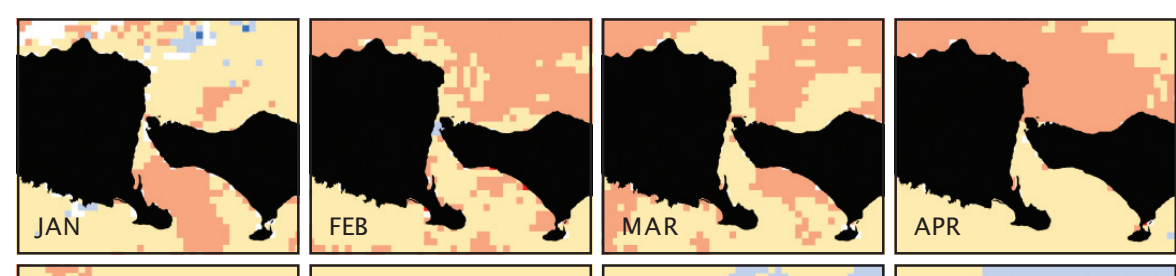

Sea surface temperature $\left({ }^{\circ} \mathrm{C}\right)$
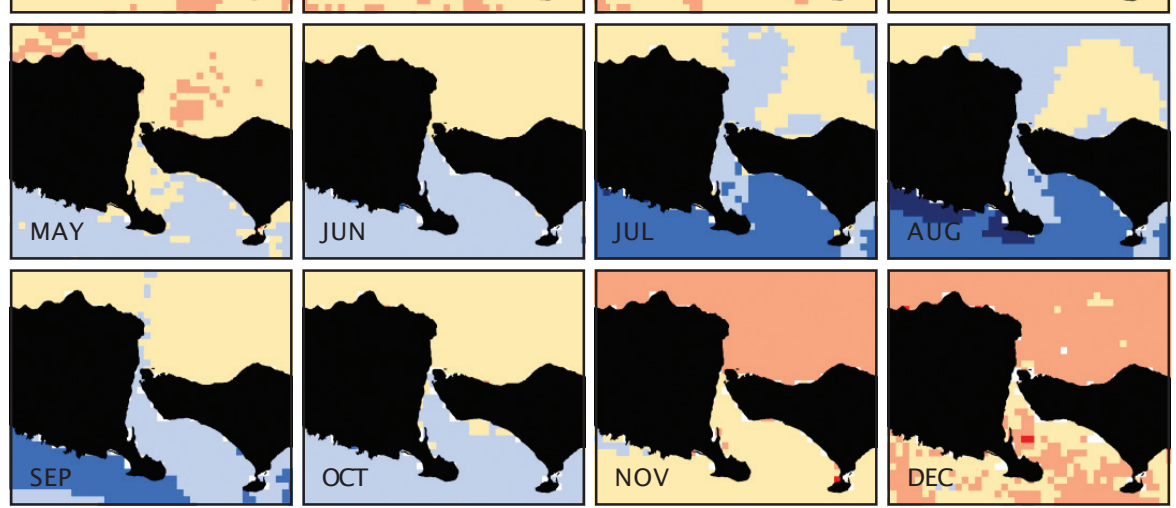

$22-24$

$24-26$

26-28

28-30

30-32

$32-34$

No data
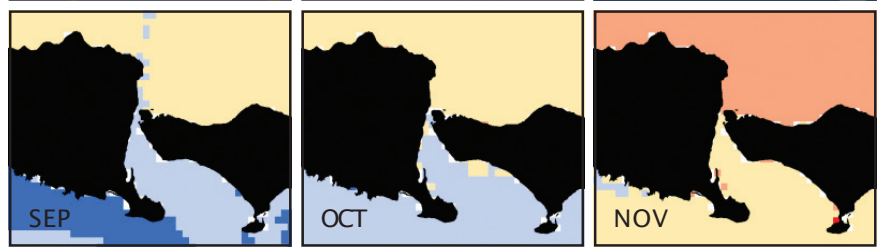

Figure 3. Monthly average of sea surface temperature derived from satellite MODIS Aqua sensor from January 2012 to December 2012. Land is presented in black colour 

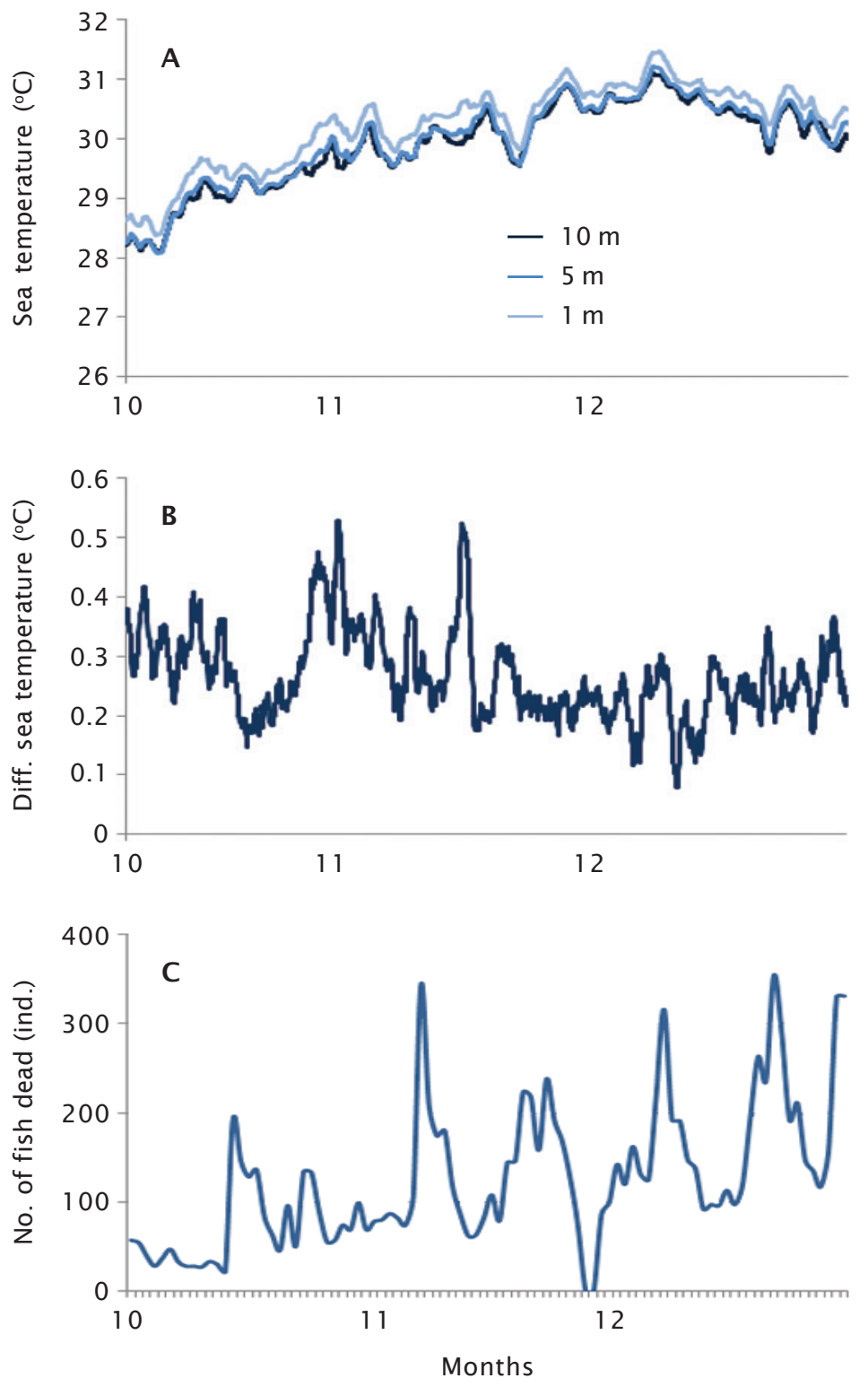

Figure 4. Moving average of stratified water temperature $(A)$ and different water temperature between $1 \mathrm{~m}$ and $5 \mathrm{~m}$ depth at station 3 (B). Number of fish died is also shown (C)

perature was fluctuated at different depth ( $\mathrm{Fi}$ gure 4A). The temperature at the surface ( $1 \mathrm{~m}$ depth) was generally warmer than the temperature at the bottom ( $5 \mathrm{~m}$ and $10 \mathrm{~m}$ ). From October to December, water temperature intended to increase. The different of temperature between $1 \mathrm{~m}$ to $5 \mathrm{~m}$ depth is shown in Figure 4B. These different water temperatures are impor- tant because in general marine fish are cultured in cages at maximum depth of 3-4m. High fluctuation of water temperature can cause fish death (Figure 4C).

When exposed to temperatures within the sublethal range, fishes can still be affected, positively or negatively, by the environmen- 
tal temperature. Temperature tolerance ranges are species-specific and include both stenothermal (narrow thermal range) species and eurythermal (wide tolerance range) (Ficke et al., 2007). Within this temperature tolerance, fish has resilience capability which is an aquatic organism's ability to recover from the changes while maintaining the processes that occur in the body, so the physiological processes in the body can take place smoothly without any interruption means.

Each fish species has different preference of optimum temperature range. Those range is generally within a few degrees. To determine the potential site having suitable water temperature to culture fish species, it is necessary to examine the ranges of water temperature in the study area. The frequency distribution of water temperature at Pegametan Bay and GRDIM, together with optimum temperature for growth of several species is presented in Figure 5. The frequency distribution indicated that Pegametan Bay was a suitable place for seabass, milkfish, and grouper aquaculture. Their optimum ranges of water temperature for growth agreed with the maximum frequency of the temperature recorded there. Although the ranges of temperature indicated suitability, the fluctuation of water temperature in the study area needed more attention especially during May-July every year.
In this study, we analyzed a short time series of the frequent monitoring of water temperature relating it with marine fish mortality and suitability range of water temperature. To have more detail connection between water temperature and fish performance, long term data are required together with availability of fish performance (growth and mortality) data.

Nearly all aquatic animals are classified as poikilotherm. Therefore, the metabolism is strongly influenced by local environmental conditions, especially water temperature. Moderate increase of temperature will result in growth and feed conversion to correct limits for each species of fish (Buentello et al., 2000). Marine fish species are also strongly influenced by temperature. Changes in water temperature also have an impact on the time and the successful migration, spawning, and the abundance of fish species. It will directly affect the level of productivity of coastal and marine environment (Walther et al., 2002; Beukema \& Dekker, 2005; Harley et al., 2006).

Water temperature changes will also be followed by other character changes, such as changes in sea level, which will be followed by changes in the composition and type of feed (Harley et al., 2006). Changes in the character of spawning and reproduction affect growth and maturity of gonads. Spawning time is strongly related to temperature, salinity,

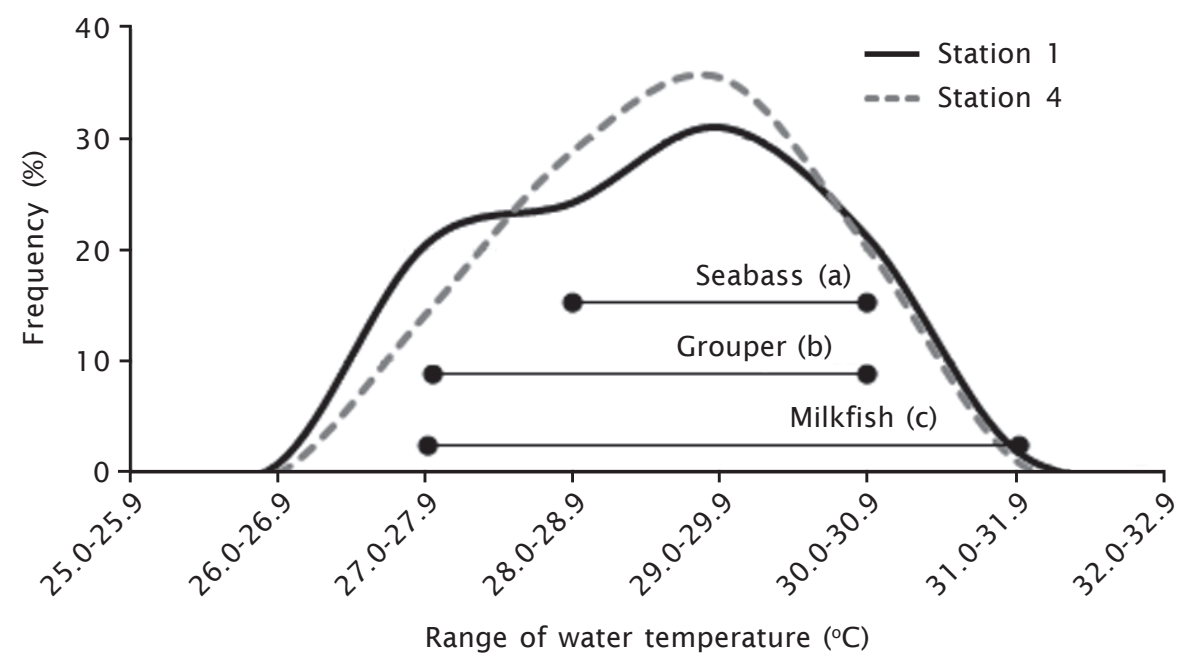

Figure 5. Temperature-dependent frequency distribution (\%) for the raw data from the frequent monitoring of water temperature at Pegametan Bay (station 1) and RDIM (station 4), Bali. (a) Rimmer (2003), (b) WWF Indonesia (2011), (c) Sudradjat (2009) 
current velocity, and biological factors such as the abundance of natural food that will provide safety larvae. Temperature has been proven to affect mature age, as occurs in Atlantic salmon (Salmosalar) (Jonsson \& Jonsson, 2004). Direct effects of climate change to marine fish condition can be seen in the occurrence of El Niño with a high intensity in 1997-1998. The impact of the El Niño and La Niña has clearly affected scallop cultivation in Hokkaido (Baba et al., 2009). El Niño events affect the low availability of scallop spat, while the presence of La Niña resulted in slow growth of scallops. Both of these climate phenomena have obviously affect reproduction and growth of scallops cultivated in Hokkaido, Japan.

\section{CONCLUSIONS}

Temperature should be monitored routinely due to temperature change. The present studies indicated that water temperature frequently fluctuated in Pegametan Bay, Bali, with maximum water temperature occurs in December and minimum water temperature occurs in March. The range of water temperatures in the study areas is still suitable for mostly marine fish species cultured in that area. Frequent monitoring of water temperature demonstrated in this study was an example how fluctuated water temperature can effect fish mortality.

\section{ACKNOWLEDGEMENTS}

The authors acknowledge to Gondol Research and Development Institute for Mariculture (GRDIM) in Bali for facilitating this study. We also thanks to Mr. Tatam Sutarmat and GRDIM cage culture team for their assistance during the field work.

\section{REFERENCES}

Albert, V., \& Ransangan, J. (2013). Effect of water temperature on susceptibility of culture marine fish species to vibriosis. International Journal of Research in Pure and Applied Microbiology, 3(3), 48-52.

Baba, K., Sugawara, R., Nitta, H., Endou, K., \& Miyazono, A. (2009). Relationship between spat density, food availability, and growth of spawners in cultured Mizuhopecten yessoensis in Funka Bay: concurrence with ENSO. Canadian Journal of Fisheries and Aquatic Sciences, 66, 6-17.

Beukema, J.J., \& Dekker, R. (2005). Decline of recruitment success in cockles and other bivalve in the Wadden Sea: possible role of climate change, predation on postlarvae and fisheries. Marine Ecology Progress Series, 287, 149-167.

Buentello, J.A., Gatlin III, D.M., \& Neil, W.H. (2000). Effects of water temperature and dissolved oxygen on daily feed consumption, feed utilization and growth of channel catfish (Ictalurus punctatus). Aquaculture, 182, 339-352.

Callaway, R., Shin, A.P., Grenfell, S.E., Bron, J.E., Burnell, G., Cook, E.J., Crumlish, M., \& Shields, R. (2012). Review of climate change impact on marine aquaculture in the UK and Ireland. Aquatic Conservation: Marine and Freshwater Ecosystem, 22, 389421.

Cane, M.A., Clement, A.C., Kaplan, A., Kushnir, Y., Pozdnyakov, D., Seager, R., Zebiak, S.E., \& Murtugudde, R. (1997). Twentiest-century sea surface temperature trends. Science, 275, 957-960.

De Silva, S.S., \& Soto, D. (2009). Climate change and aquaculture: potential impacts, adaptation and mitigation. In Cochrane, K., De Young, C., Soto, D., \& Bahri, T. (Eds.), Climate change implications for fisheries and aquaculture: overview of current scientific knowledge. FAO Fisheries and Aquaculture Technical Paper. No. 530. FAO. Rome, p. 151-212.

Ficke, A.D., Myrick, A.A., \& Hansen, L.J. (2007). Potential impacts of global climate change on freshwater fisheries. Rev. Fish Biol. Fisheries, 17, 581-613.

FAO Fisheries and Aquaculture Department. (2011). World Aquaculture 2010 . FAO Fisheries and Aquaculture Department. Technical Paper. No. 500/1. FAO. Rome, 105 pp.

GESAMP (IMO/FAO/Unesco-IOC/WMO/WHO/ IAEA/UN/UNEP Joint Group of Experts on the Scientific Aspects of Marine Environmental Protection). (1996). Monitoring the ecological effects of coastal aquaculture wastes. Rep. Stud. GESAMP No. 57, 38 pp.

GESAMP (IMO/FAO/Unesco-IOC/WMO/WHO/ IAEA/UN/UNEP Joint Group of Experts on the Scientific Aspects of Marine Environmental Protection).(2001). Planning and management for sustainable coastal aquaculture development.FAO Rep. Stud. GESAMP No. 68, 90 pp.

Harley, C.D.G., Hughes, R.A., Hultgren, K.M., Miner, B.G., Sorte, C.J.B., Thornber, C.S., Rodriguez, L.F., Tomanek, L., \& Williams, S.L. 
(2006). The impacts of climate change in coastal marine systems. Ecol. Lett., 9, 228241.

Intergovernmental Panel on Climate Change [IPCC]. (2007). Summary for policymakers. In Climate change 2007: the physical science basis. Contribution of working group I to the fourth assessment report of the intergovernmental panel of climate change [Solomon, S., Qin, D., Manning, M., Chen, Z., Marquis, M., Averyt, K.B., Tignor, M., \& Miller, H.L. (Eds.)]. Cambridge University Press, Cambridge, United Kingkom and New York, NY. USA, 18 pp.

Jonsson, N., \& Jonsson, B. (2004). Size and age of maturity of Atlantic salmon correlate with the North Atlantic Oscillation Index (NAOI). J. Fish Biol., 64, 241-247

Kementerian Kelautan dan Perikanan [KKP]. (2011). Kelautan dan Perikanan dalam Angka 2011 . Kementerian Kelautan dan Perikanan. Jakarta, 122 pp.

Rimmer, M. (2003). Barramundi. In Lucas, J.S., \& Southgate, ... (Eds.), Aquaculture Farming Aquatic Animals and Plants. Fishing News Books. Blackwell Publishing. Blackwell Publishing Ltd, 9600 Garington Road, Oxford, UK, 364-381 p.
Savtchenko, A., Ouzounov, D., Ahmad, S., Acker, J., Leptoukh, G., Koziana, J., \& Nickless, D. (2004). Terra and aqua MODIS product available from NASA GES DAAC. Advance Space Research, 34, 710-714.

Stickney, R.R. (2009). Aquaculture: an Introductory Text. $2^{\text {nd }}$ Edition. Cambridge University Press, Cambridge, 305 pp.

Sudradjat, A. (2009). Budidaya 23 komoditas laut menguntungkan. Penebar Swadaya. Jakarta, 172 pp.

Wada, M., Hatanaka, K., Saville, R., Radiarta, I N., \& Sugama, K. (2013). Marine observation framework using ICT for mariculture in Indonesia. OCEAN 13 conference San Diego, September 23-26, 2013, 6 pp.

Walther, G-R., Post, E., Convey, P., Menzel, A., Parmesan, C., Beebee, T.J.C., Fromentin, JM., Hoegh-Guldberg, O., \& Barlein, F. (2002). Ecological responses to recent climate change. Nature, 416, 389-395.

World Wildlife Fund [WWF] Indonesia. (2011). Budidaya ikan kerapu sistem keramba jaring apung dan tancap. Beter Management Practice. Seri Panduan Perikanan Skala Kecil. WWF Indonesia. Jakarta, 18 p 